\title{
Isolation and characterization of two distinct types of HcRNAV, a single-stranded RNA virus infecting the bivalve-killing microalga Heterocapsa circularisquama
}

\author{
Yuji Tomaru ${ }^{1}$, Noriaki Katanozaka ${ }^{2,3}$, Kensho Nishida ${ }^{1}$, Yoko Shirai ${ }^{1}$, \\ Kenji Tarutani ${ }^{1}$, Mineo Yamaguchi ${ }^{1}$, Keizo Nagasaki ${ }^{1, *}$ \\ ${ }^{1}$ National Research Institute of Fisheries and Environment of Inland Sea, 2-17-5 Maruishi, Ohno, Saeki, Hiroshima 739-0452, Japan \\ ${ }^{2}$ SDS Biotech K.K., 2-1 Midorigahara, Tsukuba, Ibaraki 300-2646, Japan \\ ${ }^{3}$ Present address: Hitec Co. Ltd., 1-8-30 Tenmabashi, Kita, Osaka 530-6025, Japan
}

\begin{abstract}
HcRNAV, a novel single-stranded RNA (ssRNA) virus specifically infecting the bivalvekilling dinoflagellate Heterocapsa circularisquama, was isolated from the coastal waters of Japan. HcRNAV strains were divided into 2 types based on intra-species host-range tests. The 2 types showed complementary strain-specific infectivity. In the following experiments, typical strains of each type (HcRNAV34 and HcRNAV109), were characterized. Both virus strains were icosahedral, ca. $30 \mathrm{~nm}$ in diameter, and harbored a single molecule of ssRNA approximately $4.4 \mathrm{~kb}$ in size. Thus, in morphology and nucleic acid type, HcRNAV is distinct from HcV, the previously reported large double-stranded DNA virus infecting $H$. circularisquama. Virus particles appeared in the cytoplasm of the host cells within $24 \mathrm{~h}$ post-infection, and crystalline arrays or unordered aggregations of virus particles were observed. The burst size and latent period were estimated at $3.4 \times 10^{3}$ to $2.1 \times 10^{4}$ infectious particles cell ${ }^{-1}$ and 24 to $48 \mathrm{~h}$, respectively. To our knowledge, this is the first report of a ssRNA virus infecting dinoflagellates that has been isolated and maintained in culture. Although HcRNAV is considered to have some similarities with plant viruses belonging to genera Sobemovirus and Luteovirus, further genomic analysis is required to discuss the detailed classification and nomenclature of HcRNAV. The finding of RNA viruses infecting microalgae such as HaRNAV (Heterosigma akashiwo RNA virus) and HcRNAV emphasizes the diversity of algicidal viral pathogens.
\end{abstract}

KEY WORDS: Dinoflagellate $\cdot$ Phycovirus $\cdot$ ssRNA viruses $\cdot$ Heterocapsa circularisquama $\cdot$ Algal virus

\section{INTRODUCTION}

Viruses, or virus-like particles (VLPs), have been observed in numerous phytoplankton species (Van Etten et al. 1991, Reisser 1993, Proctor 1997, Wommack \& Colwell 2000). These observations have led to increased interest in the role of algal viruses in aquatic environments. Some reports suggest that viruses are significant agents sustaining the intra-species diversity of microalgae (Tarutani et al. 2000, Lawrence et al. 2001) and directly controlling the population dynamics of phytoplankton by viral lysis
(Suttle et al. 1990, Bratbak et al. 1993, Nagasaki et al. 1994, Tarutani et al. 2000, Jacquet et al. 2002). In addition, viral lysis of algal cells facilitates material cycle in aquatic environments, and the growth and succession of heterotrophic microbial communities (Gobler et al. 1997, Castberg et al. 2001). Thus, viruses infecting microalgae are regarded as an important member of the microbial community affecting the nutrient cycle in aquatic environments (Fuhrman 1999). To further determine the significance of aquatic viruses, it is necessary to bring more host-virus systems into the laboratory. 
So far, at least 14 algal host-virus systems have been reported to be cultured and studied to any extent. Most viruses infecting eukaryotic microalgae that have been isolated so far are large double-stranded DNA (dsDNA) viruses, which are considered as belonging to the family Phycodnaviridae (Van Etten 2000, Van Etten et al. 2002). They are icosahedral in shape, large $(>100 \mathrm{~nm})$, and harbor a dsDNA measuring 158 to $560 \mathrm{kbp}$ in length (Van Etten \& Meints 1999, Sandaa et al. 2001).

Reports of small $(<100 \mathrm{~nm})$ viruses and VLPs within algae have been comparatively rare. Brussaard et al. (1996) observed small VLPs (50 to $60 \mathrm{~nm}$ in diameter) in Emiliania huxleyi (Prymnesiophyceae) that coexisted intracellularly with larger VLPs. Neither of these VLPs were isolated. Recently, Lawrence et al. (2001) isolated a small virus (ca. $30 \mathrm{~nm}$ in diameter) infecting the harmful algal bloom-causing microalga Heterosigma akashiwo (Raphidophyceae). This virus, called HaNIV, replicates in the nucleus. HaNIV does not appear to be a member of the Phycodnaviridae, although its genome has not been characterized yet. Microalgal viruses harboring RNA genomes have recently been isolated, including: a double-stranded RNA (dsRNA) virus, MpRNAV, infecting Micromonas pusilla (Prasinophyceae) (C.P.D. Brussaard pers. comm.) and a single-stranded RNA (ssRNA) virus, HaRNAV, infecting H. akashiwo (Tai et al. 2003). The former harbors 11 segments of dsRNA and proliferates itself in the cytoplasm, and the latter has ca. $9.1 \mathrm{~kb}$ ssRNA and also replicates in the cytoplasm. These findings indicate that the diversity of microalgal viruses is undoubtedly higher than previously envisaged.

Heterocapsa circularisquama Horiguchi (Horiguchi 1995) is a harmful bloom-causing dinoflagellate that specifically kills bivalves. It was first observed in Uranouchi Bay, Japan, in 1988. A large dsDNA virus (HcV) infecting $H$. circularisquama was isolated in 1999 that likely belongs to Phycodnaviridae on the basis of morphology, genome type, and pathology (Van Etten 2000, Tarutani et al. 2001, Nagasaki et al. 2003). In the present paper we describe the characteristics of a novel ssRNA virus (HcRNAV) infectious to $H$. circularisquama, and discuss its ecological significance. As far as we know, this is the first report of a ssRNA virus that infects and lyses dinoflagellates.

\section{MATERIALS AND METHODS}

Algal cultures. Four extracellularly axenic clonal strains of Heterocapsa circularisquama, HU9433-P, HA92-1, HCLG-1 and HY9423, were used for isolation of viral pathogens. These strains were isolated from coastal waters of western Japan: Uranouchi Bay in December 1994, Ago Bay in December 1992, Gokasho Bay in August 1999, and Yatsushiro Kai in September 1994, respectively (see Fig. 1). Although H. circularisquama generally harbors intracellular bacteria that are considered to have a symbiotic relationship with the host, HU9433-P was also free of intracellular bacteria (Maki \& Imai 2001). To test the intra-species host range of the viruses, 52 additional $H$. circularisquama clonal strains were examined as potential hosts. Detailed information about these hosts is provided in Nagasaki et al. (2003). H. circularisquama strains were grown in modified SWM3 medium (Chen et al. 1969, Itoh \& Imai 1987) enriched with $2 \mathrm{nM} \mathrm{Na}_{2} \mathrm{SeO}_{3}$ under a 12:12 h light:dark cycle of 130 to $150 \mu$ mol photons $\mathrm{m}^{-2} \mathrm{~s}^{-1}$ with cool white fluorescent illumination at $20^{\circ} \mathrm{C}$. To examine the inter-species infection specificity of HcRNAV, 32 additional clonal algal strains belonging to the families Bacillariophyceae, Chlorophyceae, Dinophyceae, Euglenophyceae, Eustigmatophyceae, and Raphidophyceae (Table 1) were also tested as potential hosts. These species were cultured under the

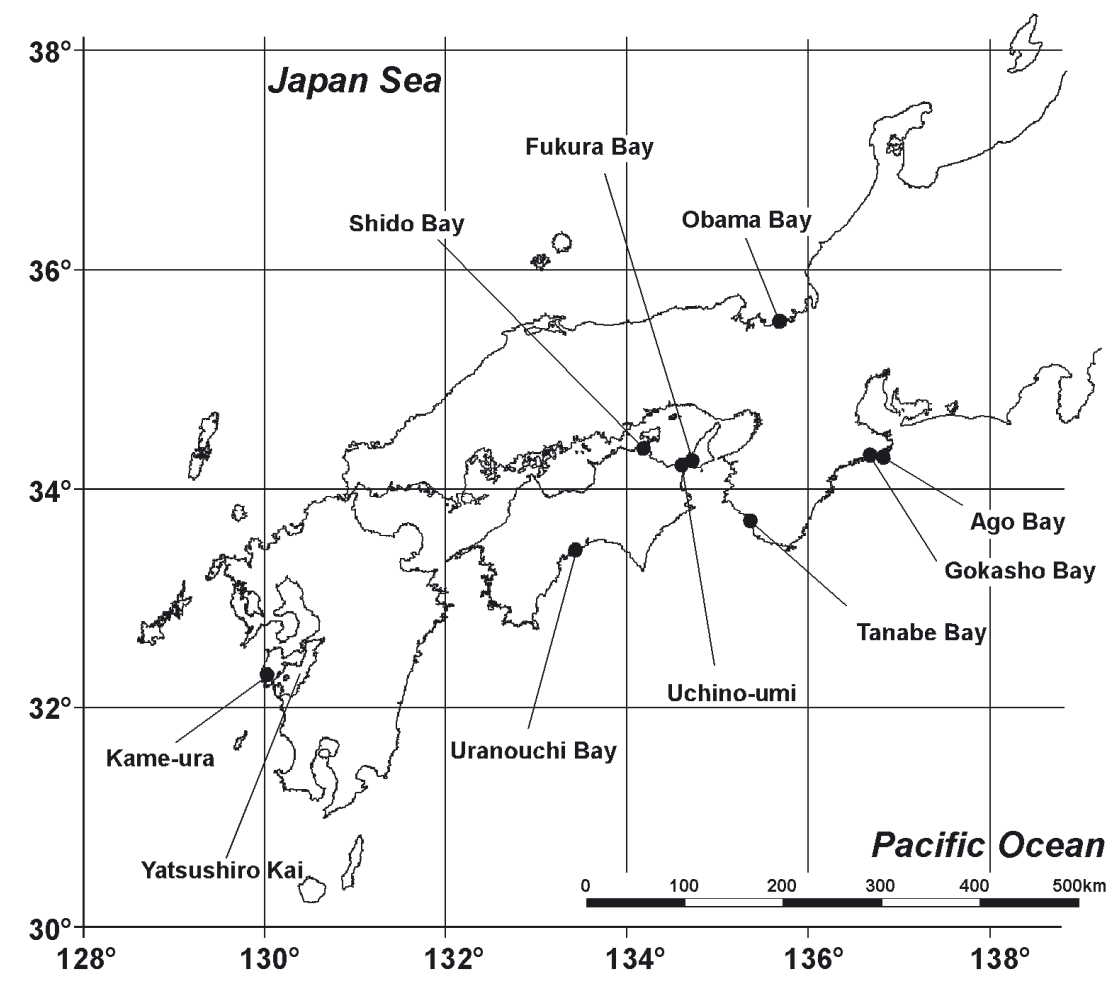

Fig. 1. Locations $(\bullet)$ from which seawater samples were collected for isolation of HcRNAV strains 
Table 1. Infection specificities of HcRNAV34 and HcRNAV109 against 36 strains of marine phytoplankton. -: not lysed; +: lysed

\begin{tabular}{|c|c|c|c|c|c|}
\hline Family & Species & $\begin{array}{l}\text { Strain } \\
\text { code }\end{array}$ & $\begin{array}{c}\text { Temperature } \\
\left({ }^{\circ} \mathrm{C}\right)\end{array}$ & $\begin{array}{c}\text { Strains lysed } \\
\text { by HcRNAV34 }\end{array}$ & $\begin{array}{c}\text { Strains lysed } \\
\text { by HcRNAV109 }\end{array}$ \\
\hline \multirow[t]{4}{*}{ Bacillariophyceae } & Chaetoceros didymum & $\mathrm{Ch} 4$ & 15 & - & - \\
\hline & Ditylum brightwellii & Dity & 15 & - & - \\
\hline & Skeletonema costatum & SK-1 & 15 & - & - \\
\hline & Thalassiosira sp. & Th2 & 15 & - & - \\
\hline Eustigmatophyceae & Nannochloropsis sp. & SFBB & 20 & - & - \\
\hline Chlorophyceae & Oltmannsiellopsis viridis & Olt & 20 & - & - \\
\hline \multirow[t]{23}{*}{ Dinophyceae } & Alexandrium catenella & $\mathrm{ACNG}$ & 20 & - & - \\
\hline & Alexandrium tamarense & AKR3 & 15 & - & - \\
\hline & Gymnodinium catenatum & Gc1ax & 20 & - & - \\
\hline & Gymnodinium mikimotoi & G303-ax2 & 20 & - & - \\
\hline & Gymnodinium sanguinum & GSUR & 20 & - & - \\
\hline & Heterocapsa circularisquama & HU9433-P ${ }^{\mathrm{a}}$ & 20 & + & - \\
\hline & Heterocapsa circularisquama & HA92-1 ${ }^{\mathrm{a}}$ & 20 & + & - \\
\hline & Heterocapsa circularisquama & HCLG-1 ${ }^{\text {a }}$ & 20 & - & + \\
\hline & Heterocapsa circularisquama & HY9423 ${ }^{\mathrm{a}}$ & 20 & - & + \\
\hline & Heterocapsa illdefina & CCMP446 & 25 & - & - \\
\hline & Heterocapsa niei & TG607 & 25 & - & - \\
\hline & Heterocapsa niei & CCMP447 & 25 & - & - \\
\hline & Heterocapsa pygmaea & AK23 & 25 & - & - \\
\hline & Heterocapsa pygmaea & CCMP1322 & 25 & - & - \\
\hline & Heterocapsa pygmaea & CCMP1490 & 25 & - & - \\
\hline & Heterocapsa sp. & CCMP451 & 25 & - & - \\
\hline & Heterocapsa sp. & CCMP450 & 15 & - & - \\
\hline & Heterocapsa triquetra & $\mathrm{Ht}$ & 15 & - & - \\
\hline & Heterocapsa triquetra & CCMP448 & 20 & - & - \\
\hline & Heterocapsa triquetra & CCMP449 & 15 & - & - \\
\hline & Prorocentrum micans & 8304 & 20 & - & - \\
\hline & Prorocentrum triestinum & Pt-1 & 20 & - & - \\
\hline & Scrippsiella sp. & SCKR & 20 & - & - \\
\hline Euglenophyceae & Eutreptiella sp. & Eut-ax01 & 20 & - & - \\
\hline \multirow[t]{6}{*}{ Raphidophyceae } & Chattonella antiqua & CaTim & 20 & - & - \\
\hline & Chattonella marina & CmUR2 & 20 & - & - \\
\hline & Chattonella ovata & $\mathrm{CoV}$ & 20 & - & - \\
\hline & Chattonella verrculosa & $\mathrm{M}$ & 15 & - & - \\
\hline & Fibrocapsa japonica & Fib-1 & 20 & - & - \\
\hline & Heterosigma akashiwo & H93616 & 20 & - & - \\
\hline
\end{tabular}

conditions given above at the temperatures shown in Table 1.

Virus isolation. Seawater was obtained from 9 sampling sites in western Japan (Fig. 1, Table 2): Gokasho Bay on 5 July 2000 (sampling depth and Heterocapsa circularisquama cell abundance were $0 \mathrm{~m}$ and unknown, respectively), Tanabe Bay on 30 August 2000 $\left(0 \mathrm{~m}, 270\right.$ cells ml $\left.\mathrm{m}^{-1}\right)$, Ago Bay from 16 July to 28 August $2001(0.5,5$ and $1 \mathrm{~m}$ above the bottom, <0.01 to 2450 cells ml-1) (details are shown in Nagasaki et al. 2004, this issue), Fukura Bay on 29 August and 4 September $2001\left(0 \mathrm{~m}, 2500\right.$ cells ml $\mathrm{m}^{-1}$ and $0 \mathrm{~m},<1 \mathrm{cell} \mathrm{ml}^{-1}$, respectively), Shido Bay on 12 September 2001 (0 m, cell abundance unknown), Obama Bay Stn Mamiyashinju and Stn Ohtsuki-shinju on 12 September 2001 (2 $\mathrm{m}, 10$ cells $\mathrm{ml}^{-1}$ and $2 \mathrm{~m}, 10$ cells $\mathrm{ml}^{-1}$, respectively), Uranouchi Bay on 27 August 2001 (0 m, cell abundance unknown), Uchino-umi Stns 5 and 6 on 15 October

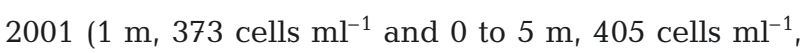
respectively), and Kame-ura on 10 December 2001 $\left(2 \mathrm{~m}, 65\right.$ cells $\left.\mathrm{ml}^{-1}\right)$. The water samples were processed within $24 \mathrm{~h}$ of sampling. Each sample was filtered through a $0.8 \mu \mathrm{m}$ nominal pore-size polycarbonate membrane filter (Nuclepore) (0.8 $\mu \mathrm{m}$ filtrate). The $0.8 \mu \mathrm{m}$ filtrate was then diluted in modified SWM3 medium in a series of 10 -fold dilution steps. Aliquots $(100 \mu \mathrm{l})$ of each dilution step were added to 8 wells in cell culture plates with 96 round-bottom wells (Falcon) containing $150 \mu \mathrm{l}$ of an exponentially growing host culture. H. circularisquama strains HU9433-P, HA92-1, HCLG-1 and HY9423 were used as potential hosts. In addition, each sample was filtered through a $0.2 \mu \mathrm{m}$ nominal pore-size membrane filter $(0.2 \mu \mathrm{m}$ filtrate) and aliquots $(1 \mathrm{ml})$ were inoculated on $1 \mathrm{ml}$ of the host culture (HU9433-P, HA92-1, HCLG-1 and HY9423). To control cultures, a $0.2 \mu \mathrm{m}$ filtrate treated at $100^{\circ} \mathrm{C}$ for 
Table 2. HcRNAV strains isolated in the western part of Japan from July through August 2000 at Gokasho Bay and Tanabe Bay, and from July through December 2001 at Ago Bay, Fukura Bay, Shido Bay, Obama Bay, Uranouchi Bay, Uchino-umi and Kameura. Only the strain numbers are shown. Note that all the strains isolated using HU9433-P or HA92-1 were categorized as UA-type, and those isolated by use of HCLG-1 or HY9423 were CY-type (refer to Fig. 2)

\begin{tabular}{|c|c|c|c|c|c|c|c|c|c|}
\hline \multirow{3}{*}{$\begin{array}{l}\text { Host strain } \\
\text { used for } \\
\text { isolation }\end{array}$} & \multirow{3}{*}{$\begin{array}{c}\text { Gokasho } \\
\text { Bay }\end{array}$} & \multirow{3}{*}{$\begin{array}{c}\text { Tanabe } \\
\text { Bay }\end{array}$} & \multicolumn{4}{|c|}{ - Isolation site of virus strains } & \multirow{3}{*}{$\begin{array}{c}\text { Uranouchi } \\
\text { Bay }\end{array}$} & \multirow{3}{*}{ Uchino-umi } & \multirow{3}{*}{ Kame-ura } \\
\hline & & & Ago & Fukura & Shido & Obama & & & \\
\hline & & & Bay & Bay & Bay & Bay & & & \\
\hline HU9433-P & & 15,16 & $\begin{array}{c}19,20,27-30 \\
43-46,59-62 \\
69-72,77-79\end{array}$ & $\begin{array}{c}85,86,89 \\
90,93,94\end{array}$ & 97,98 & & $113-116$ & 121,122 & \\
\hline HA92-1 & & 17,18 & $\begin{array}{c}21,22,31-34 \\
47,49,50 \\
63-66,73-76 \\
81-84\end{array}$ & $\begin{array}{c}87,88 \\
95,96\end{array}$ & 99,100 & & & 123,124 & 130 \\
\hline HCLG-1 & $11-14$ & & $\begin{array}{c}23,24,38 \\
51,67\end{array}$ & & 101,102 & $105-108$ & $117-120$ & 125,126 & 131 \\
\hline HY9423 & & & $39-42,68$ & 91,92 & 103,104 & $109-112$ & & 127,128 & 132 \\
\hline
\end{tabular}

5 min was added. The cell-culture plates were incubated as described above for the $H$. circularisquama cultures. The occurrence of algal lysis was monitored for 10 to $14 \mathrm{~d}$ by optical microscopy. We scored algal lysis when at least $90 \%$ of host cells in a well were lysed. In most cases when $0.8 \mu \mathrm{m}$ filtrate of a seawater sample caused algal lysis, its $0.2 \mu \mathrm{m}$ filtrate also showed an algicidal activity. For virus isolation, we used an algicidal pathogen from algal lysate induced with $0.8 \mu \mathrm{m}$ filtrates as a rule. The algicidal pathogen to HCLG-1 in Kame-ura water had to be obtained from $0.2 \mu \mathrm{m}$ filtrate, as we could not obtained it from a $0.8 \mu \mathrm{m}$ filtrate. As for seawater samples from Gokasho Bay and Tanabe Bay, only $0.2 \mu \mathrm{m}$ filtrates were examined. Clonal isolates from these algal lysates were obtained by 2 cycles of the extinction-dilution procedure (Nagasaki \& Yamaguchi 1997), using the same host strain of $H$. circularisquama that was initially used to obtain the pathogen. To eliminate bacterial contamination the lysate in the most diluted wells of the second assay was filtered through a $0.1 \mu \mathrm{m}$ nominal poresize polycarbonate membrane filter, transferred to an exponentially growing culture of the same host, and incubated as described above for the $H$. circularisquama cultures. The resultant lysate was regarded as a clonal pathogen suspension. To check the bacterial contamination in the lysate and stainability of the pathogen with DAPI (4',6-diamidino-2-phenylindole), each clonal pathogen suspension was filtered onto a $0.02 \mu \mathrm{m}$ pore-size filter (Anodisc 25, Whatman International), stained with DAPI ( $1 \mu \mathrm{g} \mathrm{ml}^{-1}$ final concentration), and observed at $1000 \times$ magnification under UV excitation. Algicidal pathogens negatively stained with uranyl acetate were also observed by transmission electron microscopy. Briefly, algicidal pathogen suspension was mounted on a grid (No. 780111630,
JEOL DATUM) for $30 \mathrm{~s}$ and excess water was removed by filter paper (No. 1, Toyo Roshi Kaisha); $4 \%$ uranyl acetate was then mounted on the grid for $10 \mathrm{~s}$ and the excess dye was removed with a filter paper. After drying the grid in a desiccator for $10 \mathrm{~min}$, negatively stained pathogens were observed by transmission electron microscopy (JEOL JEM-1010) at an acceleration voltage of $80 \mathrm{kV}$.

Host-range test. To examine the intra-species host specificity of the pathogens, clonal pathogens were screened against putative hosts to test their infectivity. Clonal pathogen suspensions were centrifuged at $4500 \times g$ for $5 \mathrm{~min}$ at $4^{\circ} \mathrm{C}$; an aliquot of each lysate was then inoculated $(1 \%, \mathrm{v} / \mathrm{v})$ independently into exponentially growing cultures of the 56 Heterocapsa circularisquama strains mentioned above. The inter-species host specificity of HcRNAV34 and HcRNAV109 was also tested by adding $5 \%$ (v/v) aliquots of each suspension to duplicate cultures of the exponentially growing algal strains listed in Table 1. The culture plates were incubated under the same conditions of light and temperature as described above for the $H$. circularisquama cultures. The occurrence of algal lysis was monitored by optical microscopy. Growth of host cultures without pathogen inoculation was also monitored to serve as a control. Algal lysis was scored when an aggregation of lysed cells was observed on the bottom of culture vessels. Algal cultures that were not lysed at $14 \mathrm{~d}$ after inoculation were scored as unsuitable hosts to the inoculum.

Based on the results of the tests, Heterocapsa circularisquama strains HU9433-P and HCLG-1 were used in the following experiments as the host of the tested virus strains HcRNAV34 and HcRNAV109, respectively.

Growth experiments. To examine the algicidal effect of HcRNAV34 and HcRNAV109, aliquots (2.5\%, v/v) of 
the pathogen suspension were filtered through a $0.1 \mu \mathrm{m}$ pore-size polycarbonate membrane filter (Nuclepore) and added to exponentially growing cultures of Heterocapsa circularisquama strains HU9433-P and HCLG-1, respectively. Cultures inoculated with an autoclaved pathogen suspension $\left(121^{\circ} \mathrm{C}\right.$, $15 \mathrm{~min}$ ) served as controls. Each treatment was run in triplicate. The titer of the pathogen was measured by means of the extinction-dilution method (Suttle 1993, Nagasaki \& Yamaguchi 1997), and the most probable number of lytic viruses was calculated (Nishihara et al. 1986). Host cell abundance was estimated by counting unfixed cells under an optical microscope using a Sedgewick-Rafter chamber.

In the 1-step growth experiment, $340 \mathrm{ml}$ of exponentially growing cultures of Heterocapsa circularisquama strains HU9433-P and HCLG-1 were inoculated with HcRNAV34 and HcRNAV109 at a multiplicity of infection (moi) of 900 and 70, respectively. (Because we could not estimate virus titers before the experiments using the extinction dilution method, which requires 10 to $14 \mathrm{~d}$ for results, it was difficult to make the moi even.) Cultures of HU9433-P and HCLG-1 inoculated with an autoclaved pathogen suspension (HcRNAV34 and HcRNAV109, respectively) served as controls. An aliquot of cell suspension was sampled from each culture at $0,12,24,33,48$ and $72 \mathrm{~h}$ after inoculation, and used to monitor the host cell abundance and pathogen titer as well as for transmission electron microscopic (TEM) observations. Pathogen titer was determined by the extinction-dilution method (Suttle 1993, Nagasaki \& Yamaguchi 1997). For TEM observations, H. circularisquama cells were harvested by centrifugation at $860 \times g$ for $10 \mathrm{~min}$ at $4^{\circ} \mathrm{C}$ and fixed with $1 \%$ glutaraldehyde at $4^{\circ} \mathrm{C}$. The cell pellets were post-fixed for $3 \mathrm{~h}$ in $2 \%$ osmic acid in $0.1 \mathrm{M}$ phosphate buffer ( $\mathrm{pH} 7.2$ to 7.4), dehydrated in a graded ethanol series, and embedded in Quetol 653 resin (NISSHIN EM). Thin sections were stained with $4 \%$ uranyl acetate and $3 \%$ lead citrate, and observed at $80 \mathrm{kV}$ using a JEOL JEM1010 TEM. The proportion of host cells harboring the small intracellular VLPs was estimated by counting at least 50 cells ( $n=50$ to $\sim 76$ ). Care was taken to ensure the same cells were not repeatedly counted in different sections. Lysed cells were not included in the counts.

Analysis of HcRNAV nucleic acid and protein. A total of $300 \mathrm{ml}$ of exponentially growing Heterocapsa circularisquama HU9433-P and HCLG-1 $\left(1.0 \times 10^{4}\right.$ to $2.0 \times 10^{4}$ cells ml ${ }^{-1}$ ) were inoculated with $3 \mathrm{ml}$ of HcRNAV34 and HcRNAV109 $\left(\sim 10^{7}\right.$ infectious titer $\left.\mathrm{ml}^{-1}\right)$, respectively, and lysed. The resulting lysates were sequentially passed through $8.0,0.8$, and $0.2 \mu \mathrm{m}$ filters to remove cellular debris. Polyethylene glycol 6000 (Wako) was added to the filtrates to obtain a final con- centration of $10 \%(\mathrm{w} / \mathrm{v})$; the resultant suspension was then stored at $4{ }^{\circ} \mathrm{C}$ in the dark overnight. After centrifugation at $57000 \times g$ for $1.5 \mathrm{~h}$, the viral pellet was washed with phosphate buffer $\left(10 \mathrm{mM} \mathrm{Na}_{2} \mathrm{HPO}_{4}\right.$ and $10 \mathrm{mM} \mathrm{KH} \mathrm{PO}_{4}$ in distilled water) and again centrifuged at $217000 \times g$ for $4 \mathrm{~h}$ to collect the virus particles; they were then resuspended in $500 \mu \mathrm{l}$ of $10 \mathrm{mM}$ phosphate buffer. The viral suspension was treated with Proteinase $\mathrm{K}$ (final conc. $=1 \mathrm{mg} \mathrm{ml}^{-1}$, Nippon Gene) in $0.1 \mathrm{M} \mathrm{NaCl}, 0.01 \mathrm{M}$ Tris- $\mathrm{HCl}$ (pH 7.4), $1 \mathrm{mM}$ EDTA and $1 \%$ sarcosyl (International Technologies) at $55^{\circ} \mathrm{C}$ for $1.5 \mathrm{~h}$ (Yamada et al. 1991). Nucleic acids were extracted by phenol-chloroform extraction (Yamada et al. 1991) and digested for $1 \mathrm{~h}$ with RNaseA (final conc. $=0.1 \mu \mathrm{g} \mathrm{ll}^{-1}$, Nippon Gene) at 37 or $98^{\circ} \mathrm{C}$, or DNaseI (final conc. $=0.2 \mu \mathrm{g} \mu \mathrm{l}^{-1}$, Promega) at $37^{\circ} \mathrm{C}$. RNase treatment at $37^{\circ} \mathrm{C}$ digests ssRNA but not dsRNA, while dsRNA denatures into ssRNA at $98^{\circ} \mathrm{C}$ and thus it is digestible with RNase. Nucleic acid extractions held on ice without enzymatic treatment served as controls. A formaldehyde-agarose gel $\left(1 \%, 15 \times 20 \mathrm{~cm}\right.$, Seakem ${ }^{\circledR}$ Gold Agarose, BMA Inc.) was loaded with $20 \mu \mathrm{l}$ of nucleic acid and electrophoresed at $50 \mathrm{~V}$ for $14.5 \mathrm{~h}$. Nucleic acids were visualized by SYBR-Green II staining (Molecular Probes).

The virus suspension was mixed with a 4 -fold volume of sample buffer $(62.5 \mathrm{mM}$ Tris- $\mathrm{HCl}, 5 \%$ 2-mercaptoethanol, $2 \%$ sodium dodecyl sulphate [SDS], $20 \%$ glycerol and $0.005 \%$ bromophenol blue) and boiled for $5 \mathrm{~min}$; then the proteins were separated by sodium dodecyl sulfate polyacrylamide gel electrophoresis (SDS-PAGE) $(80 \times 40 \times 1.0 \mathrm{~mm}, 10$ to $20 \%$ gradient polyacrylamide gel, $150 \mathrm{~V}$ ) using an XV PANTERA SYSTEM (DRC). Proteins were visualized by Coomassie brilliant blue staining. Protein molecular weight standers (DRC), ranging from 6.5 to $200 \mathrm{kDa}$, were used for size calibration.

\section{RESULTS AND DISCUSSION}

\section{Isolation of viruses and their host-range}

In the present study, pathogens to Heterocapsa circularisquama were isolated from 9 coastal waters of western Japan (Fig. 1, Table 2). Cell lysis was detected in cultures within $10 \mathrm{~d}$ of inoculation. As a result, 107 clonal pathogens were isolated: 4 from Gokasho Bay, 4 from Tanabe Bay, 52 from Ago Bay, 12 from Fukura Bay, 8 from Shido Bay, 8 from Obama Bay, 8 from Uranouchi Bay, 8 from Uchino-umi, and 3 from Kameura (Table 2). No DAPI-stainable free particles were observed in any of the pathogen samples. This indicates that the pathogens are different from a large dsDNA virus HcV (Tarutani et al. 2001). 


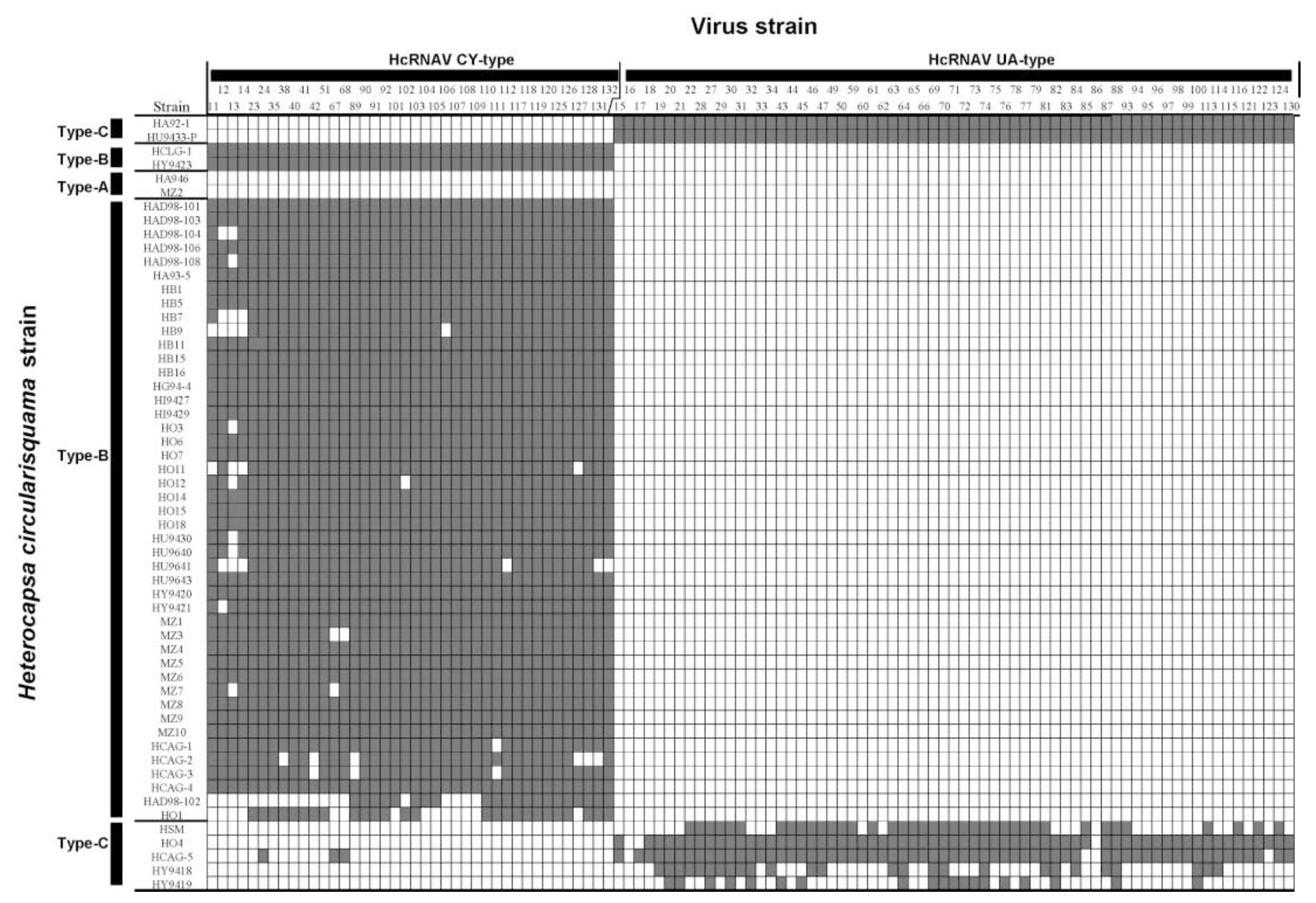

Fig. 2. Viral susceptibility spectra of 56 Heterocapsa circularisquama strains to 107 HcRNAV strains. All host and virus strains were isolated from the western part of Japan (Nagasaki et al. 2003, see our Fig. 1 and Table 2). Shaded and open columns indicate susceptibility (with cells lysed) and resistance (with cell growth equal to that of the controls) of host strains to each HcRNAV strain, respectively

Results of the intra-species host-range assay are shown in Fig. 2. The clonal pathogens were divided into 2 types on the basis of their infection spectra, UAtype and CY-type: the UA-type was composed of HcRNAV strains isolated using HU9433-P or HA92-1 as host strains, and the CY-type was composed of those isolated using HCLG-1 or HY9423 (Fig. 2, Table 2). The infection spectra of UA-type- and CY-type pathogens were complementary to each other (Fig. 2). Cluster analysis, by means of the neighbor-joining method, also supported the division of HcRNAV strains into 2 clusters (data not shown). On the basis of these results, HcRNAV34 and HcRNAV109 were selected as repre- sentatives of UA-type- and CY-type pathogens, respectively, and thereafter, the 2 typical clonal pathogens were intensively characterized.

Cell lysis occurred in Heterocapsa circularisquama cultures inoculated with HcRNAV34 or HcRNAV109 that were filtered through a $0.1 \mu \mathrm{m}$ pore-size filter. In contrast, algicidal activity was lost by autoclaving the pathogen suspension (data not shown). These data indicate that the pathogens were $<0.1 \mu \mathrm{m}$ in size and were heat-labile.

In 1-step growth experiments, Heterocapsa circularisquama cells inoculated with either pathogen contained small VLPs in the cytoplasm (Figs. 3D,E \& 4C),

Fig. 3. Heterocapsa circularisquama strain HU9433-P infected with HcRNAV34. Transmission electron micrographs. (A) Healthy cell of $H$. circularisquama HU9433-P showing the nucleus (N), chloroplasts (Ch) and pyrenoids (Py). (B) $24 \mathrm{~h}$ post-infection showing the development of viroplasms (arrows) in the cytoplasm. (C) $33 \mathrm{~h}$ post-infection showing the degradation of organelles and the expanded viroplasm (VP). (D,E) Higher magnification of the (D) crystalline array formation and (E) an unordered aggregation of HcRNAV34. (F) Negatively stained HcRNAV34 particles in the culture lysate 

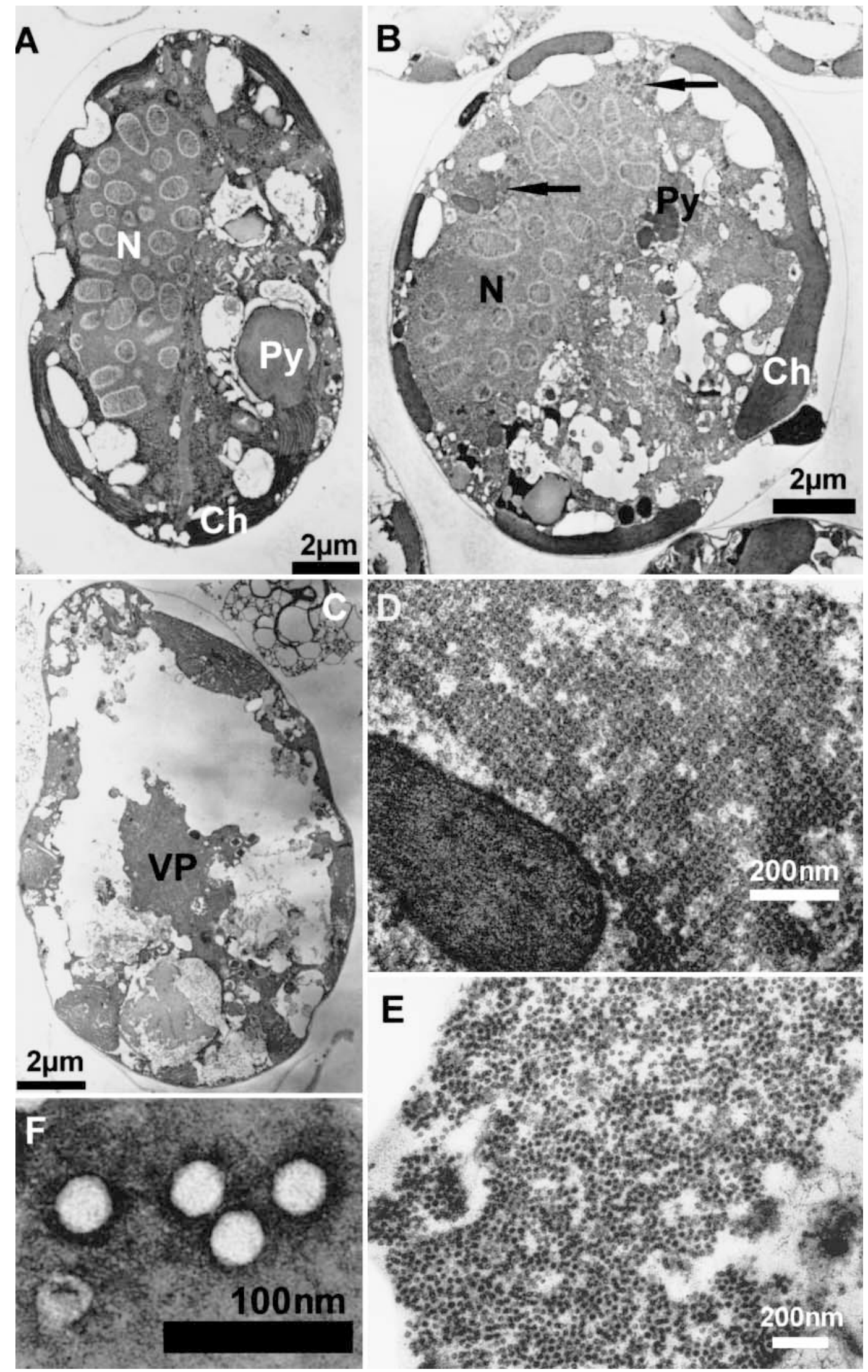




Fig. 4. Heterocapsa circularisquama strain HCLG-1 infected with HcRNAV109. Transmission electron micrographs. (A) Healthy cell of $H$. circularisquama HCLG-1 showing the nucleus $(\mathrm{N})$, chloroplasts $(\mathrm{Ch})$ and pyrenoids (Py). (B) $48 \mathrm{~h}$ post-infection showing the development of viroplasms (VP) and degradation of organelles in the cytoplasm. (C) Higher magnification of the crystalline array formation of HcRNAV109. (D) Negatively stained HcRNAV109 particles in the culture lysate

and VLPs similar in size were also observed in negatively stained culture lysates (Figs. 3F \& 4D). Healthy $H$. circularisquama cells in the control cultures had cytoplasmic structures typical of dinoflagellates with no symptoms of viral infection (Figs. 3A \& 4A). Although VLPs formed either crystalline arrays or unordered aggregations in the cytoplasm (Figs. 3D,E \& $4 \mathrm{C})$, regular array structures were only occasionally observed in thin sections.

On the basis of these results, it was demonstrated that (1) the pathogenic effect was transferable to a fresh algal culture, (2) VLPs appeared in lysed cultures, and (3) VLPs were not detected in healthy cultures. Koch's postulates were fulfilled, and thus it was concluded that the VLPs observed within the pathogen-inoculated cultures were lytic viruses infecting Heterocapsa circularisquama. We designated the pathogen HcRNAV (Heterocapsa circularisquama RNA virus), and the isolated virus strains were numbered as shown in Table 2 .
Results of the inter-species host-range test are shown in Table 1. HcRNAV34 and HcRNAV109 were not lytic to the 32 strains of marine phytoplankton, including 11 strains of the genus Heterocapsa, except for $H$. circularisquama. Considering that each HcRNAV clone was not lytic to all of the $H$. circularisquama strains tested (Fig. 2), HCRNAV is rather strain-specific than species-specific.

Strain-specificities of algal viruses have been reported in some host-virus systems, Heterosigma akashiwo-HaV (Nagasaki \& Yamaguchi 1998), H. akashiwo-HaNIV (Lawrence et al. 2001), and Micromonas pusilla-MpV (Sahlsten 1998). Tarutani et al. (2000) reported that the majority of $H$. akashiwo cells surviving after bloom disintegration caused by viral infection were resistant to most simultaneously isolated $\mathrm{HaV}$ strains, and suggested that viral control of the clonal composition of $H$. akashiwo populations may occur in natural environments. Thus, viruses are considered to affect not only the quantity (biomass) of the bloom but also the diversity of strains (quality) within the population. 


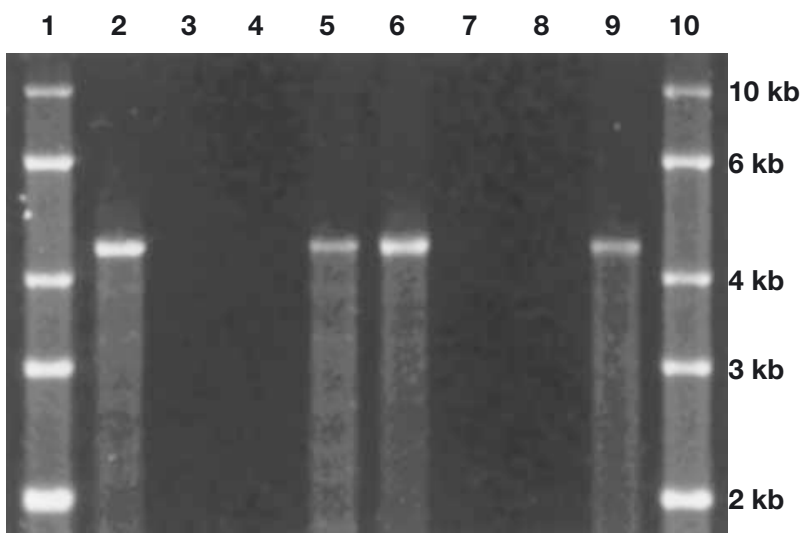

Fig. 5. Nuclease treatments of the nucleic acids isolated from HcRNAV34 (Lanes 2 to 5) and HcRNAV109 (Lanes 6 to 9). HcRNAV nucleic acids are shown untreated in Lanes 2 and 6 , after treatment with RNaseA at $37^{\circ} \mathrm{C}$ in Lanes 3 and 7, after treatment with RNaseA at $98^{\circ} \mathrm{C}$ in Lanes 4 and 8, and DNaseI at $37^{\circ} \mathrm{C}$ in lanes 5 and 9 , respectively. RNA molecular weight markers are shown in Lanes 1 and 10

\section{Morphology, genome, and protein of HcRNAV}

The particles of HcRNAV34 and HcRNAV109 were revealed to be tail-less and lack an external membrane. They were icosahedral in shape and measured approximately $30 \pm 2 \mathrm{~nm}$ (mean $\pm \mathrm{SD}, \mathrm{n}=24$ ) in diameter (Figs. 3D-F, 4C,D). With regard to the similarities in size, icosahedral structure, virus assembly in cytoplasms, and infectivity to microalgae, HcRNAV is considered to be most closely related to HaRNAV, a

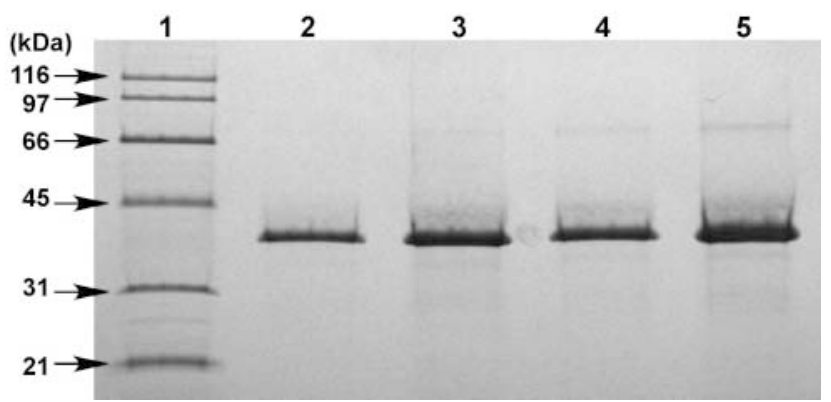

Fig. 6. Major proteins of Heterocapsa circularisquama RNA viruses. Proteins extracted from HcRNAV34 were loaded in Lanes $2(2 \mu l)$ and $3(4 \mu \mathrm{l})$, and those from HcRNAV109 were loaded in Lanes $4(2 \mu \mathrm{l})$ and $5(4 \mu \mathrm{l})$. Molecular weight markers are shown in Lane 1

single-stranded RNA virus that infects the harmful algal bloom-causing phytoplankton Heterosigma akashiwo (Tai et al. 2003).

Denaturing gel electrophoresis revealed that each virus strain had a single molecule of a nucleic acid approximately $4.4 \mathrm{~kb}$ in length that was sensitive to RNaseA both at 37 and $98^{\circ} \mathrm{C}$, but not to DNaseI (Fig. 5). These data indicate that the HcRNAV genome is ssRNA. Considering that the genome size of the icosahedral RNA viruses smaller than $30 \mathrm{~nm}$ ranges from 3.4 to $15.5 \mathrm{~kb}$ (Tidona \& Darai 2002), the genome size of HcRNAV is relatively small. As the RNAs isolated from HcRNAV34 and HcRNAV109 were not retained by a poly (A) tail purification column but recovered from the wash (data not shown), the HcRNAV genome prob-









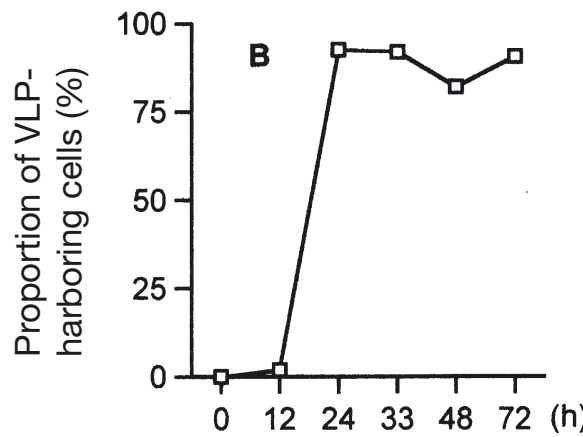

Fig. 7. Heterocapsa circularisquama. Changes in density in 1-step growth experiments. (A) HU9433P vs. HcRNAV34, the initial multiplicity of infection (moi) was 900. (B) \% of host cells harboring virus particles in the total surviving cells $(\mathrm{n}>50)$ in (A). (C) HCLG-1 vs. HcRNAV109, the initial moi was 70. (D) \% of cells harboring virus-like particles in the total surviving cells $(\mathrm{n}>50)$ in $(\mathrm{C}) .(\mathrm{A}, \mathrm{C})$ - : with addition of HcRNAV suspensions filtered through $0.2 \mu \mathrm{m}$ pore-size filter; 口: with addition of an autoclaved filtrate (negative control); O: viral titer (infectious units $\mathrm{ml}^{-1}$; error bars indicate the $95 \%$ confidence intervals) 
ably does not contain a poly (A) tail. Partial sequences of HcRNAV34 and HcRNAV109 genomes are now under way (data not shown), and indicate that the nucleotide sequences of HcRNAV34 and HcRNAV109 are similar to each other. Although HcRNAV is similar to Sobemovirus and Luteovirus with respect to morphology (25 to $30 \mathrm{~nm}$, icosahedral), nucleic acid (single molecule of ssRNA, 4.1 to $5.7 \mathrm{~kb}$ ) and replication site (cytoplasm) (Tidona \& Darai 2002), preliminary genome sequence analysis reveals that they are not closely related (data not shown). Detailed reports on the genomic organization and classification of HcRNAV will be published elsewhere.

The protein analysis shows that both HaRNAV strains have 1 major polypeptide with a molecular weight of ca. $38 \mathrm{kDa}$ (Fig. 6). In comparison, the morphologically similar algal virus HaRNAV has several (at least 5) major polypeptides with molecular weights of 24.0 to $33.9 \mathrm{kDa}$ (Tai et al. 2003), and the plant viruses Sobemovirus and Luteovirus have 3 major proteins (12 to $106 \mathrm{kDa}$ ) and 6 major proteins (4 to $60 \mathrm{kDa}$ ), respectively (Tidona \& Darai 2002).

\section{Pathology and growth characteristics of HcRNAV}

When cultures of Heterocapsa circularisquama were inoculated with an appropriate strain of HcRNAV, infected host cells lost motility and settled onto the bottom of the incubation vessel. The proportion of virus-harboring cells rapidly increased from 12 to $24 \mathrm{~h}$ post-inoculation (Fig. 7B,D). Discrimination between virus-harboring cells and healthy cells requires careful scanning by transmission electron microscopy, because intracellular structures of infected cells remain mostly intact in the early stages of infection (Fig. 3A,B). In the present observation, only cells harboring a crystalline array or unordered aggregation of small VLPs in a cytoplasm were regarded as those infected by HcRNAV. The pathological appearances, such as degradation of the cytoplasm structure, organelles, and nucleus, were clear at 33 to $48 \mathrm{~h}$ post-infection, and during this period the newly formed virus particles appeared in the cytoplasm (Figs. 3C \& 4B). A decline in cell number was observed from 24 to $48 \mathrm{~h}$ postinfection, while virus abundances showed a considerable increase in the medium from 33 to $48 \mathrm{~h}$ postinfection (Fig. 7A,C). Hence, the latent period of HcRNAV was estimated to be 24 to $48 \mathrm{~h}$, which is shorter than that of $\mathrm{HcV}$ (Tarutani et al. 2001). The increase of viral abundance was not parallel with a decreasing cell number. This makes it difficult to obtain a reliable estimate of the burst size. Viruses just released from lysed cells may form a clustered aggregation, e.g. Fig. 3D,E, and an apparent increase in viral titer may be caused by aggregation degradation. Assuming that all the cells disrupting at 24 to $48 \mathrm{~h}$ postinfection contributed to the increase in viral abundance, the burst size of HcRNAV34 and HcRNAV109 was estimated at $2.1 \times 10^{4}$ and $3.4 \times 10^{3}$ infectious units cell $^{-1}$, respectively, which are 1.6 to 10 times higher than that of $\mathrm{HcV}$. In the present experiments, as there was no dilution step after adsorption period, readsorption of the newly produced viruses might have caused an underestimation of the calculated burst size. In addition, these data should be translated with care because the burst size can be affected by moi (Van Etten et al. 1983, Bratbak et al. 1998). Still, it is considered that HcRNAV has a higher replication rate and higher yield than that of $\mathrm{HcV}$ (1800 to 2440 infectious units cell ${ }^{-1}$, Nagasaki et al. 2003). The burst size of HcRNAV was 1 to 3 orders of magnitude higher than those ever reported for the large algal viruses ( $>100 \mathrm{~nm}$ in diameter, DNA algal viruses), but 1 to 2 orders of magnitude less than that of the small algal virus HaNIV (reviewed in Castberg et al. 2002).

HcRNAV did not cause complete lysis of host cultures; ca. 10 to $20 \%$ of host cells survived even at $72 \mathrm{~h}$ post-infection (Fig. 7A,C). Most of the surviving host cells were immotile and had lost their theca (Fig. 8) and they often re-grew in the culture lysate (data not shown). TEM observations revealed that 9 to $17 \%$ of cells contained no virus particles and showed no symptoms of viral infection, such as degradation of cyto-


Fig. 8. Heterocapsa circularisquama. Optical microphotographs of HU9433-P (A) before and (B) after inoculation of HcRNAV34 (72 h post-infection). S: survived cell; L: lysed cell. Scale bars $=$ $10 \mu \mathrm{m}$ 
plasms or organelle at $72 \mathrm{~h}$ post-infection of HcRNAV (Fig. 7B,D). On the other hand, these data should be translated with care because it is possible that virusharboring cells are so delicate that they lyse during TEM preparation (thin sectioning, concentration, dehydration and embedding) (Bratbak et al. 1993). In addition, since TEM observation of a cell gives only the image of a cell section, cells with a few virus-like particles are difficult to detect. Thus, the proportion of virus harboring cells might have been under-estimated.

TEM observation suggested that the surviving cells may act as seeds for the re-growth of host populations. Survival of host cells was also observed during HcV infection (Tarutani et al. 2001, Nagasaki et al. 2003), but the survival mechanism is unknown. To understand the population dynamics of Heterocapsa circularisquama in nature, elucidation of this survival mechanism is essential.

\section{Implications}

In the present study, we examined the characteristics of the novel ssRNA virus HcRNAV, which infects the bivalve-killing dinoflagellate Heterocapsa circularisquama. As far as we know, this is the second report of ssRNA viruses infecting a microalga, the first being HaRNAV, which infects the fish-killing raphidophyte H. akashiwo (Tai et al. 2003). Furthermore, MpRNAV, a dsRNA algal virus which infects the cosmopolitan phytoplankter Micromonas pusilla, has been also isolated. It is icosahedral, 50 to $60 \mathrm{~nm}$ in diameter, and harbors 11 segments of dsRNA, the total size of which is $24.6 \mathrm{kbp}$ (C. P. D. Brussaard pers. comm.).

Most of the microalgal viruses isolated so far are large dsDNA viruses; $\mathrm{MpV}$ and $\mathrm{CbV}$ have been classified in the family Phycodnaviridae as well as the typical virus PBCV-1 infecting an exsymbiotic Chlorella-like alga (Van Etten 2000), and PpV (Jacobsen et al. 1996), BtV (Gastrich et al. 1998), HaV (Nagasaki \& Yanaguchi 1997), HcV (Tarutani et al. 2001), EhV (Wilson et al. 2002, Schroeder et al. 2002), PoV, and CeV (Sandaa et al. 2001) are also similar in size, shape, and genome type. Therefore, they may belong to the family Phycodnaviridae. Since novel RNA algal viruses such as HcRNAV, HaRNAV (Tai et al. 2003) and MpRNAV (C. P. D. Brussaard pers. comm.) have also been isolated so far, however, a new classification will have to be developed.

Host range studies revealed the diversity in the Heterocapsa circularisquama strains as well as that in the HcRNAV strains. Based on the virus sensitivity spectra, $H$. circularisquama strains were divided into 3 types: no lysis for both type of HcRNAV, lysed by HcRNAV CYtype, and lysed by HcRNAV UA-type (Fig. 2). Cluster analysis by means of the neighbor-joining method also supported this categorization (data not shown). More than a single type of $H$. circularisquama strains were isolated together from a seawater sample; e.g. $\mathrm{HO} 4$ and the other HO strains from Obama Bay in August 1997, HY9418-9419 and other HY strains from Yatsushiro Kai in September 1994. The results indicate that studies on algal viruses could lead to an understanding of diversity within the host algal species in natural environments. In addition, multiple types of host and virus strains were isolated together from Ago Bay on 16 August 2001: the host strains HCAG-5 (Type C) and HCAG-2 to 4 (Type B), and the virus strains HcRNAV19 to 22 (UA-type) and HcRNAV23 to 24 (CY-type) (Fig. 2, Table 2). Because multiple types of HcRNAV and $H$. circularisquama coexisted in a given geographical area (Fig. 2, Table 2), it is likely that HcRNAV potentially plays a significant role in determining the composition of host strains, as well as affecting the dynamics of the $H$. circularisquama population in nature (Nagasaki et al. 2004). However, the ecological implications of the diversity of $\mathrm{H}$. Circularisquama and its virus HcRNAV have not yet been fully explained. To address this issue, it is first necessary to clarify the mechanisms that support and determine diversity among host and virus clones.

Acknowledgements. This study was supported by the Industrial Technology Research Grant Program in 2001 from the New Energy and Industrial Technology Development Organization of Japan (NEDO), the Society for Techno-innovation of Agriculture, Forestry and Fisheries (STAFF), and the Ministry of Agriculture, Forestry and Fisheries, Japan. Authors are grateful to Dr. T. Uchida of the Hokkaido National Fisheries Research Institute, Japan, Drs. S. Itakura and Y. Matsuyama of the National Research Institute of Fisheries and Environments of Inland Sea, Japan, and Dr. I. Imai, Kyoto University, Japan, who kindly provided Heterocapsa strains. Thanks are also due to Mr. K. Nakanishi and Mr. N. Hata of the Mie Prefectural Science and Technology Promotion Center, Dr. T. Takeuchi of the Wakayama Research Center of Agriculture, Forestry and Fisheries, Mr. T. Ishikawa of the Kochi Prefectural Fisheries Experimental Station, Mr. A. Mizuta of the Hyogo Prefectural Awaji Civil Affairs Bureau, Mr. N. Yoshimura of the Kumamoto Prefectural Fisheries Research Center, and Mr. K. Hibino of the Fukui Prefectural Reinan Promotion Branch Office, who kindly provided seawater samples. Authors are also thankful to Drs. T. Okuno and K. Mise of Kyoto University for their technical advice on viral RNA analysis. Map drawing softwear was provided by Mapmap 4 (The Geographical Survey Institute, Japan [H13 No. 367]).

\section{LITERATURE CITED}

Bratbak G, Egge JK, Heldal M (1993) Viral mortality of the marine alga Emiliania huxleyi (Haptophyceae) and termination of algal blooms. Mar Ecol Prog Ser 93:39-48

Bratbak G, Jacobsen A, Heldal M, Nagasaki K, Thingstad F (1998) Virus production in Phaeocystis pouchetii and its relation to host cell growth and nutrition. Aquat Microb Ecol 16:1-9

Brussaard CPD, Kempers RS, Kop AJ, Riegman R, Heldal M 
(1996) Virus-like particles in a summer bloom of Emiliania huxleyi in the North Sea. Aquat Microb Ecol 10:105-113 Castberg T, Larsen A, Sandaa RA, Brussaard CPD and 5 others (2001) Microbial population dynamics and diversity during a bloom of the marine coccolithophorid Emiliania huxleyi (Haptophyta). Mar Ecol Prog Ser 221:39-46

Castberg T, Thyrhaug R, Larsen A, Sandaa RA, Heldal M, Van Etten JL, Bratbak G (2002) Isolation and characterization of a virus that infects Emiliania huxleyi (Haptophyceae). J Phycol 38:767-774

Chen LCM, Edelstein T, McLachlan J (1969) Bonnemaisonia hamifera Hariot in nature and in culture. J Phycol 5: 211-220

Fuhrman JA (1999) Marine viruses and their biogeochemical and ecological effects. Nature 399:541-548

Gastrich MD, Anderson OR, Benmayor SS, Cosper EM (1998) Fine structure analysis of viral infection in the harmful brown alga Aureococcus anophagefferens. In: Reguera B, Blanco J, Fernandez ML, Wyatt T (eds) Harmful algae. Xunta de Galicia and IOC of UNESCO, Santiago de Compostela, p 419-421

Gobler CJ, Hutchins DA, Fisher NS, Cosper EM, SanudoWilhelmy SA (1997) Release and bioavailability of C, N, $\mathrm{P}, \mathrm{Se}$ and $\mathrm{Fe}$ following viral lysis of marine chrysophyte. Limnol Oceanogr 42:1492-1504

Horiguchi T (1995) Heterocapsa circularisquama sp. nov. (Peridiniales, Dinophyceae), a new marine dinoflagellate causing mass mortality of bivalves in Japan. Phycol Res 43:129-136

Itoh K, Imai I (1987) Raphidophyceae. In: Japan Fisheries Resource Conservation Association (ed) A guide for studies of red tide organisms. Shuwa, Tokyo, p 122-130 (in Japanese)

Jacobsen A, Bratbak G, Heldal M (1996) Isolation and characterization of a virus infecting Phaeocystis pouchetii (Prymnesiophyceae). J Phycol 32:923-927

Jacquet S, Heldal M, Iglesias-Rodriguez D, Larsen A, Wilson WH, Bratbak G (2002) Flow cytometric analysis of an Emiliania huxleyi bloom terminated by viral infection. Aquat Microb Ecol 27:111-124

Lawrence JE, Chan AM, Suttle CA (2001) A novel virus (HaNIV) causes lysis of the toxic bloom-forming alga Heterosigma akashiwo (Raphidophyceae). J Phycol 37: $216-222$

Maki T, Imai I (2001) Relationships between intracellular bacteria and the bivalve killer dinoflagellate Heterocapsa circularisquama (Dinophyceae). Fish Sci 67:794-803

Nagasaki K, Yamaguchi M (1997) Isolation of a virus infectious to the harmful bloom causing microalga Heterosigma akashiwo (Raphidophyceae). Aquat Microb Ecol 13:135-140

Nagasaki K, Yamaguchi M (1998) Intra-species host specificity of $\mathrm{HaV}$ (Heterosigma akashiwo virus) clones. Aquat Microb Ecol 14:109-112

Nagasaki K, Ando M, Itakura S, Imai I, Ishida Y (1994) Viral mortality in the final stage of Heterosigma akashiwo (Raphidophyceae) red tide. J Plankton Res 16:1595-1599

Nagasaki K, Tomaru Y, Tarutani K, Katanozaka N, Yamanaka S, Tanabe H, Yamaguchi M (2003) Growth characteristics and intra-species host specificity of a large virus infecting the dinoflagellate Heterocapsa circularisquama. Appl Environ Microbiol 69:2580-2586

Nagasaki K, Tomaru Y, Nakanishi K, Hata N, Katanozaka N, Yamaguchi M (2004) Dynamics of Heterocapsa circularisquama (Dinophyceae) and its viruses in Ago Bay, Japan. Aquat Microb Ecol 34:219-226

Nishihara T, Kurano N, Shinoda S (1986) Calculation of most

Editorial responsibility: Gunnar Bratbak

Bergen, Norway probable number for enumeration of bacteria on microcomputer. Eisei Kagaku 32:226-228 (in Japanese with English abstract)

Proctor LM (1997) Advances in the study of marine viruses. Microsci Res Tech 37:136-161

Reisser W (1993) Viruses and virus-like particles of freshwater and marine eukaryotic algae-a review. Arch Protistenkd 143:257-265

Sahlsten E (1998) Seasonal abundance in Skagerrak-Kattegat coastal waters and host specificity of viruses infecting the marine photosynthetic flagellate Micromonas pusilla. Aquat Microb Ecol 16:103-108

Sandaa RA, Heldal M, Castberg T, Thyrhaug R, Bratbak G (2001) Isolation and characterization of two viruses with large genome size infecting Chrysochromulina ericina (Prymnesiophyceae) and Pyramimonas orientalis (Prasinophyceae). Virology 290:272-280

Schroeder DC, Oke J, Wilson WH (2002) Coccolithovirus (Phycodnaviridae): characterization of a new large dsDNA algal virus that infects Emiliania huxleyi. Arch Virol 147:1685-1698

Suttle CA (1993) Enumeration and isolation of viruses. In: Kemp PF, Sherr E, Cole JJ (eds) Handbook of methods in aquatic microbial ecology. Lewis Publishers, Boca Raton, FL, p 121-137

Suttle CA, Chan AM, Cottrell MT (1990) Infection of phytoplankton by viruses and reduction of primary production. Nature 347:467-469

Tai V, Lawrence JE, Lang AS, Chan AM, Culley AI, Suttle CA (2003) Characterization of HaRNAV, a single-stranded RNA virus causing lysis of Heterosigma akashiwo (Raphidophyceae). J Phycol 39:343-352

Tarutani K, Nagasaki K, Yamaguchi M (2000) Viral impacts on total abundance and clonal composition of the harmful bloom-forming phytoplankton Heterosigma akashiwo. Appl Environ Microbiol 66:4916-4920

Tarutani K, Nagasaki K, Itakura S, Yamaguchi M (2001) Isolation of a virus infecting the novel shellfish-killing dinoflagellate Heterocapsa circularisquama. Aquat Microb Ecol 23:103-111

Tidona CA, Darai G (2002) The Springer index of viruses. Springer, Berlin

Van Etten JL (2000) Phycodnaviridae. In: Van Regenmortel MHV, Fauquet CM, Bishop DHL, Carsten EB and 7 others (eds) Virus taxonomy, classification and nomenclature of viruses, 7th report. Academic Press, San Diego, CA, p 183-193

Van Etten JL, Meints RH (1999) Giant viruses infecting algae. Annu Rev Microbiol 53:447-494

Van Etten JL, Burbank DE, Xia Y, Meints RH (1983) Growth cycle of a virus, PBCV-1, that infects Chlorella-like algae. Virology 126:117-125

Van Etten JL, Lane LC, Meints RH (1991) Viruses and viruslike particles of eukaryotic algae. Microbiol Rev 55: 586-620

Van Etten JL, Graves MV, Müller DG, Boland W, Delaroque N (2002) Phycodnaviridae-large DNA algal viruses. Arch Virol 147:1479-1516

Wilson WH, Tarran GA, Schroeder D, Cox M, Oke J, Malin G (2002) Isolation of viruses responsible for the demise of an Emiliania huxleyi bloom in the English Channel. J Mar Biol Assoc UK 82:369-377

Wommack KE, Colwell RR (2000) Virioplankton: viruses in aquatic ecosystems. Microbiol Mol Biol Rev 64:69-114

Yamada T, Higashiyama T, Fukuda T (1991) Screening of natural water for viruses which infect Chlorella cells. Appl Environ Microbiol 57:3433-3437

Submitted: March 27, 2003; Accepted: August 22, 2003

Proofs received from author(s): February 10, 2004 